ELORE (ISSN 1456-3010), vol. 16 - 2/2009.

Julkaisija: Suomen Kansantietouden Tutkijain Seura ry.

[http://www.elore.fi/arkisto/2_09/katsaus_martikainen_2_09.pdf]

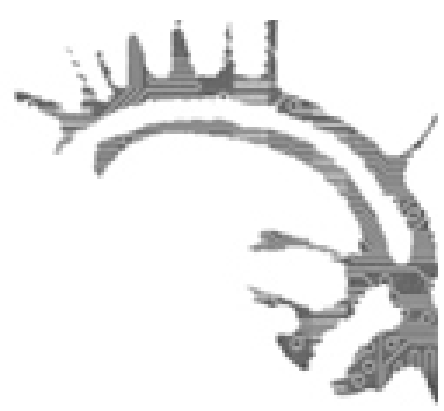

KATSAUS

\title{
EETTISIÄ KYSYMYKSIÄ MAAHANMUUTTOTUTKIMUKSESSA
}

\section{Tuomas Martikainen}

Kansainvälinen muuttoliike ja siihen liittyvä maahanmuuttajaväestön kasvu eri puolilla maailmaa on noussut merkittäväksi ilmiöksi viime vuosikymmenien aikana. Maailmassa arvioidaan olevan tällä hetkellä yli 190 miljoonaa mahanmuuttajaa (Castles \& Miller 2009, 5). OECD-maissa maahanmuuttajia oli väestöstä vajaa 12 prosenttia (keskiarvo) vuonna 2006. Maahan- ja maastamuuton vaikutus vaihtelee hyvin paljon eri alueilla (OECD 2008). Suomi muuttui 1980-luvun kuluessa maastamuuttomaasta maahanmuuttomaaksi. Muutos nopeutui 1990-luvulla, ja vuonna 2008 maassa asui 219000 ulkomailla syntynyttä, joilla oli 120000 Suomessa syntynyttä lasta. Näin ollen maahanmuuttajataustaisten osuus on noin 6 prosenttia koko väestöstä (Tilastokeskus 2009; Väänänen \& al. 2009, 15).

Aluksi on tärkeää määritellä muutamia katsauksen kannalta keskeisiä käsitteitä. Maahanmunttajaksi märitttelen henkilön, joka on syntynyt Suomen rajojen ulkopuolella ja asuu pysyväisluontoisesti Suomessa. Näiden niin sanottujen ensimmäisen sukupolven maahanmunttajien lisäksi tulen viittaamaan heidän joko toisen maahanmuuttajan tai suomalaisen kanssa saamiinsa lapsiin, eli ns. toiseen sukupolveen. Yhdessä näitä ryhmiä kutsun maahanmunttajataustaisiksi (Martikainen \& Tiilikainen 2007, 18). Näen maahanmuuton tai maahanmuuttajataustan yhdeksi henkilön tai ryhmän elämään vaikuttavaksi tekijäksi tai muuttujaksi, jonka merkitys vaihtelee yksilöstä ja tilanteesta riippuen. Maahanmuutto on riippumaton muuttuja esimerkiksi kansalaisuudesta, etnisyydestä tai uskonnosta, mutta tietyissä yhteyksissä nämä ja muut taustatekijät limittyvät toisiinsa, jolloin esimerkiksi maahanmuuttotaustan, kansalaisuuden ja etnisyyden välinen raja hämärtyy. Analyyttisesti nämä ja muut tekijät on kuitenkin mahdollista erotella toisistaan. 


\section{TuOMas Martikainen}

Maahanmuuttotutkimuksessa tutkitaan siis henkilöitä, jotka ovat pysyvästi tai toistaiseksi siirtyneet valtiosta toiseen. Nämä henkilöt elävät usein mutta eivät välttämättä jonkinlaisessa vähemmistöasemassa uudessa yhteiskunnassa. Lisäksi on huomattava, että pysyvän muuttoliikkeen lisäksi maailmassa on suuri määrä erilaisia tilapäisiä kansainvälisen liikkumisen muotoja, kuten turismi, liikematkustaminen ja kausityöläisyys, mutta ne jätän tämän katsauksen tarkastelun ulkopuolelle. Maahanmuuton tutkimus on kasvanut voimakkaasti eri puolilla viime vuosikymmeninä ja Suomessa erityisesti kuluneen 15 vuoden aikana. Maahanmuuttotutkimus ei periaatteessa eroa muusta tutkimuksesta tutkimusetiikan osalta, mutta siinä on eräitä erityispiirteitä, joita on syytä pohtia ja jotka on tärkeä huomioida tutkimusprosessissa. Nämä ovat samankaltaisia kuin muussakin vähemmistötutkimuksessa, mutta tutkittavien henkilöiden ja ryhmien alkuperän ollessa muualla maailmassa tähän tulee lisäsävyjä.

Tutkimusetiikalla ymmärrän tässä yhteydessä tutkijan pohdinnat ja valinnat tutkimusprosessiin liittyvistä eettisistä kysymyksistä, joissa mietitään esimerkiksi tutkimuksen oikeutusta ja sen mahdollisia seurauksia tutkimuskohteille (vrt. Duvell \& Triandafyllidou \& Vollmer 2008; Karjalainen \& al. 2002; Kuula 2006). Tässä artikkelissa käyn lävitse kolmen asian vaikutusta maahanmuuttotutkimukseen ja niiden eettisiä ulottuvuuksia. Nämä asiat ovat tieteellisen tutkimuksen vieraus, tutkijan ja tutkittavan välinen valta-asema ja metodologinen nationalismi. Tieteellinen tutkimus sosiaalisena toimintana ja tiedontuottamisen muotona on outoa osalle maahanmuuttajista. Tämä ei luonnollisesti koske kaikki maahanmuuttajia, mutta osalle tieteellinen tutkimus on varsin tuntematon toimintatapa (Tiilikainen 2003, 109-112). Tutkijan ja tutkittavien välinen valta-asema on usein väistämätön osa tutkimusprosessia. Tämä korostuu erityisesti haavoittuvien ryhmien, kuten ns. laittomien maahanmuuttajien kohdalla, ja ylipäätään kun valta-asemaltaan erilaiset ihmiset ovat tekemisissään toistensa kanssa (Duvell \& Triandafyllidou \& Vollmer 2008). Metodologiseksi nationalismiksi kutsuttu yhteiskuntatieteiden taipumus tarkastella tutkimuskysymyksiä kansallisista lähtökohdista käsin on haaste aineiston keräämisestä tulkintaan (Wimmer \& Glick Schiller 2002).

\section{SUOMALAINEN MAAHANMUUTTOTUTKIMUS}

Suomalainen maahanmuuttotutkimus nykymuodossaan on melko tuore tieteenala. Alan kehityksestä ja sen monimuotoisuudesta saa varsin hyvän kuvan tutustumalla toimitettuihin bibliografioihin ja tutkimuskatsauksiin (esim. Domander 1993; ETNO 1999, 2004; Väänänen \& al. 2009). Kyseessä on erittäin poikkitieteellinen tutkimusalue, jossa tosin yhteiskuntatieteiden asema on keskeinen, vaikka tutkimusta tehdäänkin lähes kaikissa ihmistieteissä (Puuronen 2006). Suomessa on aikaisemminkin tutkittu aihepiiriä, erityisesti kansallisen vähemmistötutkimuksen ja historiallisen sïrtolaisuustutkimuksen piirissä, mutta uusi maahanmuuttotutkimus on huomattavasti laajaalaisempaa ja lisäksi se määrittyy osaksi moniarvoistuvaa, myöhäismodernia Suomea. Kun 1990-luvun alussa aihepiiristä kiinnostuneita oli pieni joukko, niin 2000-luvun alussa aktiivisia tutkijoita oli jo toista sataa. 


\section{EETTISIÄ KYSYMYKSIÄ MAAHANMUUTTOTUTKIMUKSESSA}

Tutkimusaluetta kutsutaan kansainvälisen mallin mukaisesti etnisten subteiden ja kansainvälisen munttoliikekeen tutkimukseksi. Etnisten suhteiden nähdään viittaavan erilaisiin "yhteisöihin" ja sitä kautta tutkimusalue on jatkoa mm. brittiläiselle yhteisötutkimukselle. Ylipäätään angloamerikkalainen tutkimus on merkittävä lähtökohta koko alalle, osin johtuen näiden maiden kommunitaristisesta yhteiskuntaperinteestä ja merkittävästä asemasta globaalissa tiedemaailmassa. 1980-luvun lopulle tultaessa perinteinen yhteisötutkimus oli tullut tiensä päähän ja se sai vaikutteita jälkikolonialistisesta ja nousussa olevasta globalisaatiotutkimuksesta. Tällöin kansainvälisten muuttoliikkeiden tutkimus nivoutui osaksi etnisyystutkimusta ja aloitti uudenlaisen käsitteellisen vallankumouksen. Tällöin alkoi puhe mm. "uusista etnisyyksistä" (engl. new ethnicities), "kolmannesta tilasta" (engl. third space) ja hybridisaatiosta (Albrow \& al. 1996). Tästä johtuu tutkimusalueen nykyinen nimi, joka siis yhdistää yhteisö- ja muuttoliiketutkimusta. Käytän tässä yhteydessä tutkimusalueesta synonyymina nimitystä maahanmuuttotutkimus, koska se on nimenä lyhyempi ja kuvaa varsin hyvin tutkimusalueen keskeistä kiinnostuksen kohdetta: Suomessa asuvia maahanmuuttajia ja heihin liittyviä kysymyksiä.

Tutkimusalan järjestäytyminen tarjoaa yhden näkökulman maahanmuuttotutkimuksen kehitykseen. Aihepiiristä kiinnostuneiden kasvun myötä Suomen Akatemia rahoitti Syrjäytyminen, eriarvoisuns ja etniset subteet Suomessa (SYREENI) -tutkimusohjelman vuosina 2001-2003. SYREENIn päätyttyä perustivat siinä toimineet tutkijat uudeksi yhteistyöalustaksi tieteellisen Etnisten subteiden ja kansainvälisen munttoliikkeeen tutkimuksen seura ry (ETMU) -yhdistyksen kesäkuussa 2003. Malli yhdistykselle tuli Ruotsista, jossa vastaava IMER-förbundet (IMER, ruots. internationell migration och etniska relationer) oli toiminut aktiivisesti jo 1990-luvun alusta lähtien. Vuodesta 2004 lähtien järjestettyjen Etmu-päivien kävijämäärä on vakiintunut 100-200 henkeen, joka kertoo tasaisesta kiinnostuksesta aihepiiriä kohtaan. Lisäksi seuralla on yli 300 jäsentä, ja se julkaisee omaa vapaan saatavuuden (engl. open access) tieteellistä aikakauslehteä Finnish Journal of Ethnicity and Migration (ks. <http://www.etmu.fi/fjem/>). Tutkijoiden nopea institutionalisoituminen on esimerkki uudella tutkimusalalla olleesta kysynnästä, vaikka muutoin ala on vasta löytämässä paikkaansa suomalaisessa yliopistomaailmassa.

Monimuotoisuudestaan huolimatta maahanmuuttotutkimusta yhdistää muutama seikka. Tutkimus on keskittynyt tiettyihin vähemmistöryhmiin ja -kansallisuuksiin. Näitä ovat erityisesti venäläiset ja somalialaiset. Muuttosyyn näkökulmasta pakolaiset, turvapaikanhakijat ja inkeriläiset paluumuuttajat ovat saaneet enemmän huomiota kuin työn, opiskelun tai puolison takia muuttaneet. Erityisesti perheeseen ja avioitumiseen liittyvän muuton tutkimuksen vähäisyyttä on pidettävä puutteena, koska valtaosa maahanmuutosta on nimenomaan sitä. Suuri osa tutkimuksesta on joko erityyppisiin teksteihin tai haastatteluihin perustuvaa laadullista tapaustutkimusta. Tilastollista ja kyselyaineistoihin perustuvaa tutkimusta toki on, mutta niiden osuus on varsin pieni kokonaisuudesta. Tässä mielessä tutkimus heijastelee sosiaalitieteiden laadullista käännettä, jossa kvantitatiivisten tutkimusten osuus on aikaisempaa huomattavasti vähäisempi. Merkittävä osa tutkimuksesta käsittelee ns. pehmeitä aiheita, kuten syrjintää, identiteettiä ja sosiaalisia suhteita, ja niillä on emansipatorisia sävyjä. 


\section{TuOMas Martikainen}

Näin ollen suomalainen maahanmuuttotutkimus heijastelee yleistä mediakuvaa maahanmuutosta ja maahanmuuttajista kulttuurisesti erilaisina pakolaisina tai turvapaikanhakijoina ja tuo esille joko suomalaisen yhteiskunnan tai palvelujärjestelmän puutteita, kuten syrjintään ja maahanmuuttajien kieltenopetukseen liittyviä kysymyksiä. Vaikka yllä esittämäni tulkinta tutkimuksen painopisteistä osin häivyttää sen moninaisuutta, niin haluan tuoda tämän kärjistyksen kautta esille tutkimuksen yksipuolisuuden ja tarpeen itsereflektioon. Kasvanut maahanmuutto on kieltämättä tuonut esille suomalaisen yhteiskunnan varjopuolia, mutta silti tutkimuksella on vastuu luoda kokonaisvaltaista kuvaa maahanmuutosta, joka on paljon muutakin kuin ongelmia ja häiriötä - puolin tai toisin.

Maahanmuuttotutkimuksessa yhdistyvät yksittäisten tutkijoiden ja rahoittavien tahojen intressit. Usein konfliktikeskeisempään ja medioissa näkyviin ongelmiin on helpompi saada rahoitusta kuin vähemmän huomiota herättäviin hankkeisiin. Tutkimus on ikään kuin perustellumpaa, kun se suunnataan jo todennettuihin tai kuviteltuihin sosiaalisiin ja yhteiskunnallisiin ongelmiin. Maahanmuuttotutkimus kärsii lisäksi institutionaalisesti heikosta asemasta suomalaisissa yliopistoissa, minkä yhtenä seurauksena voi olla painottuminen ongelmakeskeisimpiin aiheisiin, koska jokainen hanke ja tutkielma täytyy erikseen perustella ja rahoitus hakea. Esimerkiksi omalla tutkimusalueellani uskonnon ja maahanmuuton liittymäpinnalla on jostain syystä suuri määrä tutkimusta muslimeista, kun taas ongelmattomaksi koetut kristityt maahanmuuttajat eivät ole juuri kiinnostusta herättäneet. Näin siitä huolimatta, että kristillistaustaiset muodostavat arvioilta kolme neljäsosaa kaikista maahanmuuttajista (Martikainen 2006).

\section{TeOriat}

Metodologinen nationalismi on uudehko kriittinen suuntaus maahanmuuttotutkimuksessa, joka viittaa yhteiskuntatieteellisen maahanmuuttotutkimuksen taipumukseen tulkita asioita kansallisen kehikon lävitse. Nykykeskustelun aloittaneiden Andreas Wimmerin ja Nina Glick Schillerin (2002) mukaan metodologinen nationalismi vaikuttaa kolmella eri tavalla:

1. Tutkimuksessa jätetään huomioimatta muut kuin kansallista kontekstia tukevat näkökulmat.

2. Kansallisvaltio on prosessien ja asioiden luonnollinen ympäristö.

3. Tutkimus rajoitetaan maantieteellisesti koskemaan vain tietyn maan sisällä tapahtuvia asioita.

Näillä tutkimuksen piirteillä on myös eettisiä seurauksia, sillä ne luonnollistavat kansalliset asiaintilat normaaleiksi.

Maahanmuuttotutkimuksen ehkä yleisin käsite on "etnisyys", jota yleensä käytetään suhteessa vähemmistöihin (käsitteestä, ks. Martikainen \& Sintonen \& Pitkänen 2006). Näin syntyy vaikutelma, että "etnisyys" on juuri vähemmistöjen ominaisuus, kun taas 


\section{EETTISIÄ KYSYMYKSIÄ MAAHANMUUTTOTUTKIMUKSESSA}

enemmistön "ei-etnisyys" edustaa normaalitilaa. Näin ollen enemmistöhallinta määrittyy normaaliudeksi, joka vain poikkeuksellisissa tilanteissa kyseenalaistuu. Ole Riis (2007) mainitsee tällaiseksi Jyllands-Postenin Muhammad-pilakuvakohdun yhteydessä syntyneen vaikutelman, että tanskalaiset olivatkin yllättäen vähemmistöasemassa, joskin globaalissa kontekstissa. Tällöin "tanskalaisuus" näkyi etnisyyteen verrattava ominaisuutena myös kotimaan rajojen sisäpuolella. Joka tapauksessa tutkimusasetelman rajaaminen kansallisvaltioiden sisään vaikuttaa eri toimijoiden keskinäisiin suhteisiin, jotka eivät kaikissa tilanteissa välttämättä pidä paikkaansa tai anna riittävää kokonaiskuvaa käsiteltävästä ilmiöstä.

Transnationaalisuus- eli ylirajaisuustutkimus on 1990-luvulla noussut tutkimussuuntaus, joka tutkii ihmisten rajoja ylittäviä suhteita, instituutioita ja käytäntöjä. Se on saanut paljon jalansijaa maahanmuuttotutkimuksessa, sillä yleisen globalisaation myötä ylirajaisuus on tullut aikaisempaa vaivattomammaksi, halvemmaksi ja sitä myötä yleisemmäksi. Steven Vertovec (2009, 85-86) näkeekin ylirajaisuustutkimuksen yhtenä keskeisenä seurauksena kansallisvaltion roolin kyseenalaistumisen luonnollisena tutkimuksellisena tilana. Transnationaaliset teoriat tarjoavatkin yhden apukeinon metodologisen nationalismin välttämiseksi tai ainakin sen tiedostamiseksi.

Metodologisen nationalismin tiedostamiseen liittyy myös oman yhteiskunnan teoreettinen ja diskursiivinen reflektointi. Esimerkiksi angloamerikkalaisessa etnisyystutkimuksessa "rotu" (engl. race) ja siihen liittyvät kategoriat, kuten "valkoinen" (engl. white) ja "musta" (engl. black), heijastavat sitä tapaa kuinka eri ryhmien väliset suhteet näissä maissa on järjestetty ja kategorisoitu. Näiden käsitteiden suora siirtäminen suomalaiseen yhteiskuntaan on ongelmallista, sillä meillä eivät vastaavat erottelut toimi samalla tavoin. Suomalaisessa etnisyysdiskurssissa "suomalainen" ja "ulkomaalainen" ovat edelleen keskeisiä kategorioita, joita edes yleisesti käytetty maahanmuuttaja-sana ei ilmeisesti ole vielä pystynyt syrjäyttämään. Angloamerikkalaisten postkoloniaalisten teorioiden vaikutus suomalaiseen tutkimukseen on jatkuvasti kasvussa (esim. Kuortti \& Lehtonen \& Löytty 2007), joten aika tulemme lähivuosina näkemään millä tavoin nämä vaikutteet tulevat muokkaamaan kotimaisen tutkimuksen diskursseja.

\section{Aineistot ja MENETELMÄT}

Kun tutkimuskysymykset tai -intressi on muotoiltu, niin vuorossa on aineiston hankkiminen. Suomessa tämä on tyypillisesti tarkoittanut haastattelututkimusta, sillä monista maahanmuuttajiin liittyvistä kysymyksistä puuttuu riittävästi taustatietoja jotta esimerkiksi rekisteritutkimus olisi mielekästä. Monista aihepiireistä on mahdollista saada tietoa vain henkilökohtaisen kontaktin välityksellä. Tässä vaiheessa alkaa haastateltavien etsiminen, jossa jo yhteystietojen saaminen voi olla työlästä. Monet viranomaiset ja vastaavat avainhenkilöt eivät mielellään anna tai eivät saa luovuttaa tietoja, ja joissain tapauksissa vaaditaan muodollinen suositus esimerkiksi oppiaineesta. Näin ollen jo tutkimuskohteen lähestymiseen saattaa liittyä eri toimijoiden eettistä pohdintaa siitä, mikä on suotavaa. Vaikka suomalaisessa perinnetutkimuksessa on ollut jo jonkin aikaa itsestään selvää, että tutkimuksen alussa pohditaan sen eettistä oikeutusta, niin uutena 


\section{TuOMas Martikainen}

kansainvälisenä trendinä on näiden prosessien muodollistaminen ja aiempaa tiiviimpi ankkurointi lainsäädäntöön ja virallisiin suosituksiin (Kuula 2006).

Yhteyden synnyttyä seuraava vaihe on tutkimuksen motivointi mahdollisille haastateltaville. Oman kokemukseni mukaan tämä ei yleensä ole ongelma, mutta siihen kannattaa varata aikaa erityisesti, jos haastateltavalla ei ole aikaisempaa kokemusta tutkimuksesta tai heikko kielitaito. Myös tutkijan rooli voi olla epäselvä. Onko hän viranomainen tai poliisi? Miksi kysytään tiettyjä kysymyksiä ja mihin niitä käytetään? Miksi haastattelu nauhoitetaan? Joskus huonot kokemukset viranomaisista omassa maassa tuovat oman lisänsä tutkimusasetelmaan. Nämä yleensä väistyvät kun tutustuminen etenee ja luottamus kasvaa. Haastateltavilla saattaa olla suuriakin toiveita tutkijaa kohtaa esimerkiksi oman elämänsä epäkohtien korjaamisessa. Näissä yhteyksissä on syytä olla rehellinen omista mahdollisuuksista. Lisäksi eteen voi tulla pyyntöjä avustamisesta eri yhteyksissä. Joka tapauksessa tutkimuksen alussa on lainsäädännöllisistä syistä tärkeää selvittää tutkimuksen lähtökohdat ja mahdollisesti tiedossa oleva tuleva käyttö ja sen rajoitukset.

Joskus on tarve käyttää tulkkia. Marko Juntunen (2009) kertoo värikkäästi kokemuksistaan tulkin roolista välittäjänä Turun Varissuolla artikkelissaan Diasporic Silences and Multicultural Encounters. Hänen esimerkissään suomalaisen yhdistyksen ja maahanmuuttajien tapaamisessa tulkki jätti monia merkityksiä tulkkaamatta ja saattoi kaunistella joitain puheenvuoroja. Tällä tavoin vältettiin konflikteja, mutta myös luotiin osin epärealistisia käsityksiä puolin ja toisin. Myös tulkin luotettavuus on syytä varmistaa, sillä joskus haastateltavan kertomat asiat voivat olla hänelle itselleen vahingollisia, jos ne päätyvät vääriin korviin. Virallistut tulkit ovat sitoutuneet noudattamaan eettisiä sääntöjä.

Haastattelututkimuksessa tulee väistämättä esille myös tutkijan mahdollinen tausta enemmistökulttuurista. Tämä voi korostua, jos haastattelu tehdään tutkijalle vahvemmalla kielellä, esimerkiksi suomeksi, jolloin haastateltava joutuu ilmaisemaan itseään muulla kuin äidinkielellään. Myös aikaisemmat kokemukset valtaväestöön kuuluvista voivat vaikuttaa tutustumisen alussa. Oman kokemukseni mukaan henkilön taustaan liittyvät kysymykset muuttuvat vähemmän merkityksellisiksi sitä mukaa, kun tutustuminen ja luottamus kehittyvät.

Aineistonkeruulle lisämausteensa saattaa tuoda tutkittavien ihmisten elämän monipaikkaisuus. Viime vuosina monipaikkainen etnografia (engl. multi-sited ethnography) on löytänyt tiensä yleiseksi globalisoituneen maailman tutkimusmenetelmäksi. Tässä tutkija seuraa tutkittaviansa ja heidän sosiaalisia verkostojansa eri puolille maailmaa (esim. Levitt 2001). Suomessa monipaikkaisen etnografian haasteisiin ovat tarttuneet esimerkiksi bosnialaisten osalta Laura Huttunen (2006) ja somalialaisten parissa Marja Tiilikainen (2007). Monipaikkaisen tutkimuksen myötä avautuu eri väestöryhmien ylirajainen elämä. Esimerkiksi Suomessa varsin stigmatisoitunut somalialaisten ryhmä näyttäytyy hyvin toisenlaisessa valossa, kun heidän elämänsä sijoitetaan laajempaan yhteyteen. Metodologisen nationalismin tiedostamisella voidaan siis välttää eri ryhmien yksioikoista kuvausta. 


\section{EETTISIÄ KYSYMYKSIÄ MAAHANMUUTTOTUTKIMUKSESSA}

\section{Tulkinta ja VaikuttavuUs}

Maahanmuuttotutkimuksessa ollaan usein lähtökohtaisesti kertomassa "toisesta", ja jo itse tutkimuskentän määrittely mielletään usein vähemmistöryhmien parissa työskentelyksi. Näin ei toki välttämättä tarvitsisi olla, sillä "maahanmuuttajuus" on vain osa yksilön tai ryhmien taustaa, joka ei useimmissa tilanteissa ole edes merkityksellinen. Tutkimuksella on kuitenkin osa maahanmuuttajien toiseuttamisessa. Tutkimustuloksia esittelevät usein valtaväestöön kuuluvat tutkijat. Julkaisun yhteydessä käytetyt peruskäsitteet luovat helposti mielikuvia muukalaisista, vaikka tämä ei olisikaan tarkoitus. Lisäksi tutkimusintressien legitimoimisessa käytetään usein ongelmalähtöisiä oletuksia, vaikka ne sittemmin purettaisiinkin. Tosin ei pidä ylikorostaa tutkimuksen itsenäistä vaikutusta yhteiskunnallista diskursseista ja tulkinnoista, sillä toisaalta tutkimuksen tehtävänä usein on peilata ja heijastaa sosiaalista todellisuutta. Silti kriittisellä tutkimuksella on erityinen tilaus maahanmuuttotutkimuksessa.

Kenties ongelmallisin ja vaikein tutkimuksellinen haaste vähemmistötutkimuksen parissa on kielteisistä ilmiöistä kertominen tai kertomatta jättäminen. Mikäli jonkun väestöryhmän asema on yleisesti ottaen heikko, niin tutkijoilla on taipumus jollei suojella niin ummistaa silmänsä ikäviltä asioilta. Tällaisia voivat olla esimerkiksi suomalaisessa yhteiskunnassa kielletyt tai muuten arveluttavat käytännöt tai ryhmän sisäinen vallankäyttö. Ilmiselvistä laittomuuksista kynnys kertoa viranomaisille lienee matalampi, mutta muutoin tilanne on hankala. Asian julkistaminen voi päättää hyvinkin pitkäaikaisen ja luottamuksellisen tutkimussuhteen sekä vaikeuttaa muiden ja tulevien tutkijoiden työtä. Lisäksi esimerkiksi luottamuksellisissa haastatteluissa esille tulleet asiat ovat kiusallisia, vaikka omien kokemusteni mukaan haastateltavat eivät yleensä tuo esille asioita, jotka ovat heille haitallisia, ainakaan laittomuuksia. Todennäköisempää onkin, että asiat tulevat esille vahingossa tai jonkun muun asian yhteydessä. Lisäksi usein syntyy vain epäilyksiä jonkin ilmiön olemassa olosta.

Nämä ovat todellisia eettisiä dilemmoja ainakin yksittäisinä tapauksina. Toisaalta asioiden jättäminen sikseen voi olla jonkun etnisen ryhmän maineelle parempi vaihtoehto kuin sen saattaminen julkiseen tai viranomaisten tietoon, etenkin jos näissä yhteyksissä on vaarana suuren yhteisön leimaaminen. Toisaalta asioilta on taipumusta tulla ajan mittaan esiin, jolloin ne tulevat ennemmin tai myöhemmin vastaan joka tapauksessa. Lisäksi jos kyseessä on yksittäisen ihmisen välittömään terveyteen tai henkilökohtaiseen turvallisuuteen liittyvä asia, niin jo tilanteeseen reagoimatta jättäminen on itsessään teko. Tutkija joutuukin tapauskohtaisesti miettimään, mikä on sekä kokonaisuuden että yksittäisen tilanteen kannalta eettisin toimintamalli, mitä vaikeuttaa huomattavasti se, että kaikkea olennaista tietoa ei välttämättä ole saatavilla.

\section{LOPUKSI}

Olen tässä katsauksessa keskustellut muutamista maahanmuuttotutkimukseen liittyvistä käytännöllisistä ja eettisistä kysymyksistä. Katsauksen lähtökohtana on Suomessa 1990-luvun alusta lähtien kasvanut maahanmuuttajaväestö ja sitä seurannut tutkimuk- 


\section{TuOMas Martikainen}

sellinen kiinnostus ja tarve maahanmuuttajiin liittyvistä kysymyksistä. Katsauksessa olen erityisesti kiinnittänyt huomiota tieteellisen toiminnan tuttuuteen tai tuntemattomuuteen maahanmuuttajan näkökulmasta, tutkijan valta-asemaan ja metodologiseen nationalismiin. Maahanmuuttotutkimuksessa on siis joukko eettisiä kysymyksiä, jotka luovat sille tiettyjä erityispiirteitä. Nämä liittyvät usein kielitaitoon, yhteiskuntatuntemukseen, ylirajaisuuteen, yhteiskunnalliseen valta-asemaan ja maahanmuuttotaustaan. Erityisesti valtaan liittyvissä kysymyksissä tilanne on samankaltainen kuin muussakin vähemmistötutkimuksessa. Valtaväestöstä tulevan tutkijan asema ei ole koskaan lähtökohtaisesti neutraali, vaikka se sellaiseksi voi prosessin aikana muuttuakin.

Maahanmuuton tutkimus on monessa mielessä itsensä peilaamista tutkijana. Valtaväestöstä lähtevät tiedon intressit eivät välttämättä vastaa vähemmistöryhmien omia tarpeita, ja tässä mielessä vähemmistötutkimuksella on taipumusta toimia yhteiskunnan peilinä ja vallankäytön osana. Tämä liittyy osin myös tutkimuksen kontrollifunktioon, jonka avulla tuodaan esille yhteiskunnallisia anomalioita ja mahdollisia keinoja niiden ratkaisemiseksi. Tästä syystä eettisen pohdinnan tulisi olla jatkuvaa maahanmuuttotutkimuksessa, kuten muussakin yhteiskunnallisessa tutkimuksessa.

\section{KIITOS}

Haluan kiittää käsikirjoitusta kommentoineita Lena Marander-Eklundia ja Tiina Mahlamäkeä hyvistä täydennys- ja korjausehdotuksista. Lopullisesta tekstistä kannan luonnollisesti itse vastuun.

\section{KiRJALlisuUs}

ALBROW, MARTIN \& EADE, JOHN \& DÜRRSCHMIDT, JÖRG \& WASHBOURNE, NEIL 2006: The Impact of Globalization on Sociological Concepts: Community, Culture and Milieu. - Eade, John (toim.), Living the Global City: Globalization as a Local Process. Lontoo: Routledge.

CASTELS, STEPHEN \& MILLER, MARK 2009: The Age of Migration: International Population Movements in the Modern World. Basingstoke: Palgrave Macmillan.

DOMANDER, MINNA 1993: Siirtolaisuns ja pakolaisunstutkimus Suomessa 1980-1993. Turku: Siirtolaisuusinstituutti.

DUVELL, FRANCK \& TRIANDAFYLLIDOU, ANNA \& VOLLMER, BASTIAN 2008: Ethical Issues in Irregular Migration Research [online]. Report/Clandestino. < http://irregular-migration.hwwi.net/typo3_upload/groups/31/4.Background_ Information/4.1.Methodology/Ethical_Report_Clandestino_Feb09.pdf >

ETNO 1999: Maahanmuntto, pakolaisuus, sïrtolaisuns ja etniset vähemmistöt 1990-luvulla. Helsinki: Työministeriö.

ETNO 2004: Munttoliikkeet ja etniset vähemmistöt Suomessa 1999-2004: Tutkimukset ja tilastot. Helsinki: Työministeriö.

HUTTUNEN, LAURA 2006: Bosnialainen diaspora ja transnationaali eletty tila. Martikainen, Tuomas (toim.), Ylirajainen kulttuuri: Etnisyys Suomessa 2000-luvulla. Helsinki: SKS. 


\section{EETTISIÄ KYSYMYKSIÄ MAAHANMUUTTOTUTKIMUKSESSA}

JUNTUNEN, MARKO 2009: Diasporic Silences and Multicultural Encounters in Varissuo, Finland. - Finnish Journal of Ethnicity and Migration 4(1).

KARJALAINEN, SAKARI \& LAUNIS, VEIKKO \& PELKONEN, RISTO \& PIETARINEN, JUHANI (toim.) 2002: Tutkijan eettiset valinnat. Helsinki: Gaudemus.

KUORTTI, JOEL \& LEHTONEN, MIKKO \& LÖYTTY, OLLI (toim.) 2007: Kolonialismin jäljet: Keskustat, periferiat ja Suomi. Tampere: Vastapaino.

KUULA, ARJA 2006: Tutkimusetiikeka: Aineistojen hankinta, käyttö ja sälytys. Tampere: Vastapaino.

LEVITT, PEGGY 2001: The Transnational Villagers. Berkeley: University of California Press.

MARTIKAINEN, TUOMAS 2006: Maahanmuuttajat ja uskonto: tausta, jäsenyys, yhdyskunnat. - Laitinen, Aappo (toim.), Kristinusko Suomessa. Helsinki: Suomalainen teologinen kirjallisuusseura.

MARTIKAINEN, TUOMAS \& TIILIKAINEN, MARJA 2007: Maahanmuuttajanaiset: Käsitteet, tutkimus ja haasteet. - Martikainen, Tuomas \& Tiilikainen, Marja (toim.), Maabanmunttajanaiset: Kotoutuminen, perhe ja työ. Helsinki: Väestönliiton Väestöntutkimuslaitos.

MARTIKAINEN, TUOMAS \& SINTONEN, TEPPO \& PITKÄNEN, PIRKKO 2006: Ylirajainen liikkuvuus ja etniset vähemmistöt. - Martikainen, Tuomas (toim.), Ylirajainen kulttuuri: Etnisyys Suomessa 2000-luvulla. Helsinki: SKS.

OECD 2008: International Migration Outlook—Sopemi 2008. OECD.

PUURONEN, VESA 2006: Näkökulmia etnisten suhteiden tutkimukseen Suomessa. - Martikainen, Tuomas (toim.), Ylirajainen kulttuuri: Etnisyys Suomessa 2000-luvulla. Helsinki: SKS.

RIIS, OLE 2007: Religious Pluralism in a Local and Global Perspective: Images of the Prophet Mohammad Seen in a Danish and Global Perspective. - Beyer, Peter \& Beaman, Lori (toim.), Religion, Globalization and Culture. Leiden: Brill.

TIILIKAINEN, MARJA 2003: Arjen islam: Somalinaisten elämää Suomessa. Tampere: Vastapaino.

TIILIKAINEN, MARJA 2007: Somaliäidit ja transnationaalinen perhe. - Martikainen, Tuomas \& Tiilikainen, Marja (toim.), Maahanmunttajanaiset: Kotoutuminen, perhe ja työ. Helsinki: Väestönliiton Väestöntutkimuslaitos.

TILASTOKESKUS 2009: Väestörakenne, Syntymävaltio iän ja sukupuolen mukaan maakunnittain 1990-2008. Helsinki: Tilastokeskus.

VERTOVEC, STEVEN 2009: Transnationalism. Lontoo: Routledge.

VÄÄNÄNEN, ARI \& al. 2009: Maabanmunttajien integroituminen suomalaiseen ybteiskuntaan elämän eri osa-alueilla. Esiselvitysraportti. Helsinki: Työterveyslaitos, kuntoutussäätiö \& Terveyden ja hyvinvoinninlaitos.

WIMMER, ANDREAS \& GLICK-SCHILLER, NINA 2002: Methodological nationalism and beyond: nation-state building, migration and the social sciences. - Global Networks 2(4).

Filosofian tohtori, dosentti Tuomas Martikainen työskentelee Suomen Akatemian tutkijatohtorina Åbo Akademin uskontotieteessä. 